\title{
10. Digital platform work in Latin America: challenges and perspectives for its regulation ${ }^{1}$
}

\author{
Graciela Bensusán and Héctor Santos
}

\section{INTRODUCTION}

During the first two decades of the twenty-first century, a diverse range of companies offering services through digital platforms and intelligent technological devices connected to the internet emerged globally. These companies encouraged those willing to provide services to sign up as self-employed workers. In some cases, this business model obscured the labour relationship between companies and workers and exemplifies what is known as the 'the disappearance of the employer' (Degryse 2019). That is, companies who fail to register workers with social security systems and to recognize their labour rights, thus contributing to labour informality in the countries in which they operate (Berg and De Stefano 2016). The issue of digital platform employment is thus an important one in the study of labour markets and constitutes an enormous challenge for both the state and social actors in Latin America.

Some specialists argue that platforms are an opportunity for labour formalization as their growth in developing countries, in addition to generating employment, will inevitably lead to their regulation (Buenadicha et al. 2017). In contrast, others suggest that the prevalence of weak states in these countries allows offline platforms ${ }^{2}$ to operate at the margins of employment and other regulations. Digital platforms therefore have no incentive to encourage job formalization or to recognize workers' rights (Robinson 2015).

In light of this debate, in this chapter we argue that the quality of jobs generated by offline digital platforms will depend both on the characteristics of the platforms themselves, as well as on the opportunities and restrictions faced by states and social actors (unions, principally) to regulate the platforms and counterbalance the unilaterality of their actions. Both factors stem from the structural conditions of labour markets, as well as from power relations and political decisions, and are likely to have important consequences for workers' 
well-being and social inequality in the region. Thus, although some type of state intervention intended to curb the most detrimental social effects of the digital economy can be expected, precisely as occurred in previous industrial revolutions, responses are likely to vary and will depend largely on the instruments used as well as their scope and orientation. In fact, various countries across the region have already begun this process, and efforts to regulate work done through platforms are particularly advanced in certain developed countries, as we will show.

As a result of the evidence gathered in this chapter, we argue that platform work is often considered to be low quality but workers in Latin America seem quite satisfied with it; it offers better opportunities in terms of pay and autonomy than the local labour markets, particularly for better educated workers. At the same time, platform work threatens to further informalize the already highly informal labour markets in Latin America and to further increase already high levels of inequality. This further informalization will result in a growing percentage of the working population living in conditions of insecurity since informal workers are not covered by social security arrangements such as unemployment benefits, pensions or sickness benefits, which are often linked to formal employment in Latin America.

Platform work takes the form of informal work due to the workers being generally treated as self-employed, even though in many cases they should really be classified as employees. There is a lack of regulation and enforcement here. Weak states and weak social actors (unions) along with the refusal of the platforms to recognize their employment responsibility are at the root of this problem.

There is no single solution to these problems, which also arise in the rest of the world. However, some experiences in Latin America and further afield show that the state and social actors have a range of options with which to better regulate the platform economy and reduce informality.

To develop these arguments, this chapter is organized as follows. Section 1 provides a brief overview of the main characteristics of Latin American labour markets: informality and job insecurity. Section 2 presents the main findings of two quantitative investigations into platform work. One includes Mexico, Chile, Brazil and Colombia. The other focuses on Argentina. We also present some perceptions of various actors in Mexico on the advisability of regulating work on platforms. Section 3 examines the central issues of this debate, as well as the main approaches to the role of the state and collective actors with regards to regulating platforms. We argue that decisions will depend upon the orientation of the different governments as well as the local characteristics and socio-political arrangements of the world of work, which will create more or less favourable structures of political opportunities for workers' protection. 
The fourth section reviews current forms of state intervention into the regulation of digital platforms, taking into account different governmental branches (legislative, judicial and administrative) and orientations (those that recognize the subordinate status of these workers as well as those that view platform workers as self-employed). We examine the situation both regionally and internationally. Here, the case of Mexico serves to illustrate how a change in governmental political orientation can create favourable conditions for the protection of the most vulnerable. Finally, our conclusions are presented.

\section{THE LABOUR MARKET IN LATIN AMERICA: INFORMALITY AND INEQUALITY}

A study conducted by CEPAL (2010, p. 160) asserts that the social and economic inequality characterizing the region is mainly due to the poor performance of labour markets and the disparities that arise as a consequence. One example is that in Latin America for every hour worked, women receive on average 17 per cent less income than men (OIT 2019a). Another significant inequality is that 18 per cent of 15-24-year-olds are unemployed, which is the more than twice the overall rate of unemployment in the region, which was 8.4 per cent in the same year (ILO 2020). Young people also registered a 62.4 per cent rate of labour informality in 2019, which is 10 per cent higher than the general rate in Latin America (ILO 2020).

Labour informality, understood as jobs outside of contributory social security systems, persists and is a serious issue in Latin America, despite the fact that some governments were able to improve levels of formality between 2003 and 2013. During this period, the regional average percentage of workers enrolled in social security systems increased from 38.3 per cent to 45.2 per cent (BID 2015). Despite this, in 2018, five out of ten employed persons worked in informal employment (OIT 2018), and eight out of ten self-employed workers were informally employed (OIT 2015). According to the ECLAC-ILO (CEPAL-OIT 2019), in 2018, self-employed work accounted for 48 per cent of employment at a regional level. It has been noted that in Latin America, paid informal work is largely involuntary, although this is also true for a significant proportion of self-employed workers (Perry et al. 2007). Given the prognosis of low economic growth for the region in the upcoming decade, and the probable limited creation of new positions of paid work, self-employed work, partly associated with work on digital platforms, is likely to increase (CEPAL-OIT 2019). Hence, there is a need to prevent workers who sign on to digital platforms from falling into involuntary informality.

In Latin America, labour market inequalities are linked to access to or exclusion from social security systems, according to the type of employment. In general terms, there are two varieties of social protection schemes in Latin 
America. One is contributions-based social security, linked to standard formal employment and with a low rate of coverage. Among its benefits are pensions and health insurance. In order to finance this scheme, workers and employers make income-based contributions. The other variant is non-contributory social security, which provides coverage to those who do not have formal employment. It provides more limited benefits than contributory schemes, but it differs from these in the scope of the benefits, and the source of funding is public spending (OIT 2018, p. 15). Currently, the persistent and elevated rate of informality in the region has led to a recognition that social risks should be responded to with a combination of contributory and non-contributory social security schemes (OIT 2018).

The third issue, job insecurity, defined as unstable and insecure working conditions (affecting access to work benefits), is expressed in rates of employee turnover. In Latin America, one in four employed persons between the ages of 24 and 54 have worked in their current job for a year or less, compared to one in eight in OECD countries. Furthermore, the average length of service in Latin America is 40 per cent less than in OECD countries (BID 2015). Among the possible causes for such instability are labour informality (CONEVAL 2018), low productivity, minimal training for workers and low wages, resulting in a cycle of 'poor quality jobs' (BID 2015, p. 20).

As a result of this, digital platforms in the region are inserted into a segmented labour market, but it is not clear to what extent they could influence the tendencies described. In this sense, the platforms play an as yet uncertain role in relation to the social and economic inequality that characterizes the region and that is produced in the labour market, as CEPAL points out (2010).

\section{LATIN AMERICAN EXPERIENCES WITH PLATFORM WORK}

With the aim of examining the degree to which emerging work on platforms follows the trends described above, we now present findings from two quantitative studies. The first study focuses on Uber drivers in Mexico, Chile, Brazil and Colombia (Azuara et al. 2019), while the second looks at workers registered on a variety of platforms in Argentina (Madariaga et al. 2019). While anticipating further studies incorporating a wider range of countries, these studies provide at least an initial, general profile of platform workers. Complementarily, we present some perceptions of various actors in Mexico on the advisability of regulating work on platforms, the scope of this, as well as the advantages and disadvantages of doing so (Bensusán 2020). 


\subsection{Uber in Mexico, Chile, Brazil and Colombia ${ }^{3}$}

The study produced by Azuara, González and Keller (2019) analyses the case of Uber in Mexico, Chile, Brazil and Colombia, analysing the results of a survey conducted with 5,251 Uber drivers in those four countries.

The average age of Uber drivers in those countries is 38,93 per cent of whom are men. In these countries, 55 per cent of workers have a university degree. In general, they are workers in the prime of their working life with a good level of education.

On a regional level, almost half the Uber drivers had been informally employed before joining the company (45 per cent) (Azuara et al. 2019). This data supports Robinson's (2015) argument that regional state regulatory weakness facilitates the platforms operating at the margins of labour legislation or other laws, and thereby reproduces the tendency for informality in the region's labour markets. In addition, it partly explains the difficulty faced by these workers to organize and gain recognition as workers with rights.

Azuara and colleagues (2019, p. 14) survey shows that income levels from digital platforms are a significant incentive, equivalent to three times the national minimum wage in Mexico, Chile, Brazil and Colombia. It is also worth highlighting that, in these countries the 'average duration in the use of the platform is 19 hours per week, and the majority of Uber drivers uses it less than 30 hours per week' (Azuara et al. 2019, p. 11). Either way, this is less than the 48 hours per week legal limit in Mexico and does not even constitute the minimum of 35 hours of a full working week according to the criteria of the National Institute of Statistics and Geography (INEGI). ${ }^{4}$ In addition, it should be noted that 66 per cent of digital platform workers identify the option of flexible hours as an important motive for signing onto, and continuing to work on, these platforms. It is surprising that only 40 per cent of these workers stated that they would leave these jobs if they were offered other paid work, suggesting that the majority are satisfied with their working conditions. It should also be noted that 28 per cent are employed on more than one platform (Azuara et al. 2019).

Finally, considering the lack of asset ownership as a key indication of the nature of the relationship between workers and platforms, the fact that half of the region's Uber drivers do not own their vehicle suggests that they should be considered as subordinate workers. However, this does not necessarily mean that the platform is the employer, as workers could be considered to be in a subordinate relationship with the owner of the vehicle they rent. In summary, most of the above data challenges the digital platforms' claim that workers are self-employed, despite the fact that a significant proportion of workers may be satisfied with this condition. 
The above coincides with the findings of Eisenmeier's case study (2018) of Uber drivers in Mexico. In this case, the drivers' satisfaction is much more evident among those who have been excluded from the formal labour market, mainly due to age, and who own their vehicles. However, the author points out that this satisfaction is in decline in the face of growing competition between drivers and among platforms (Eisenmeier 2018).

Although concerns regarding the regulation of platform workers' rights could at first be seen as purely academic and lacking social support, as long as satisfaction with Uber's working conditions continues to decline, that situation could change.

\subsection{Work on Digital Platforms in Argentina}

The report for the International Labour Organization and Interamerican Bank of Development prepared by Madariaga et al. (2019), analyses the results of a survey conducted with 603 workers from ten different types of platforms. It found that the age of platform workers in Argentina is between 18 and 49, 73.7 per cent of whom are men. In this country, 37 per cent of workers have university degrees (Madariaga et al. 2019). Just like in the case of Uber drivers, in general, they are workers at the beginning of their working life with a good level of education.

In Argentina's platform economy only 55 per cent of workers contribute to social security. Almost 90 per cent of them do so as independent taxpayers, a tax regime created in Argentina for self-employed workers long before the rapid expansion of digital platforms.

In relation to work insecurity, workers from a heterogeneous group of platforms reported having been working on platforms for an average of 15 months, longer than four out of ten workers in the region who have less than a year's continuity in their current job (BID 2015). With regards to hours worked per week, 35.9 per cent of the survey's respondents reported that they work less than 20 hours, and 31.6 per cent report more than 45 hours. On average, workers on the ten platforms included in the study worked a little over 32 hours weekly (Madariaga et al. 2019, p. 100).

In terms of motives for seeking employment on these platforms, the main one reported by 30.2 per cent of respondents was the possibility of additional earnings. Furthermore, it should be noted that 29.1 per cent of digital platform workers identify the option of flexible hours as an important motive for signing onto, and continuing to work on, these platforms (Madariagae et al. 2019, p. 93).

Work through digital platforms constitutes the main source of income for 61 per cent of these workers. This contradicts the assumption that these jobs are secondary occupations, preventing workers from claiming their labour rights. 
Furthermore, in this country 22 per cent of workers surveyed are employed on more than one platform.

This suggests that most workers, by earning at least 75 per cent of their income from a single platform, meet the criterion of economic dependence used to establish workers' rights. The majority also meet the criterion of exclusivity. It has also been argued however that these characteristics distinguish a third category of work, falling between subordinated work and self-employment, as discussed below.

\subsection{The Opinions of Actors Involved in Platform Work in Mexico ${ }^{5}$}

The results of interviews conducted in Mexico with various social and governmental actors, as well as with Uber drivers and Rappi food deliverers show a general agreement for the need to regulate these jobs. Respondents also agreed that legislation was needed to establish the criteria that would determine the circumstances under which a (subordinate) employment relationship existed between platforms and workers. They also shared the concern of digital platform work becoming a new path to informality.

Respondents were given three options regarding the recognition of platform workers' rights: to decouple social security from employment status, to create new categories of workers between subordinated and self-employed work (i.e. dependent contractor in Britain, Sánchez-Urán 2018, p. 72), or to consider such workers to be subordinate in all cases, with all the rights that this would entail. Interestingly, some digital platform workers emphatically stated that they would not sacrifice their autonomy for labour rights, reflecting the dominant argument against regulation.

Finally, it was recognized that relations between the platforms and the actors interested in labour regulation (federal governments and the government of Mexico City) have been sporadic and have failed to produce results (Bensusán 2020). According to respondents, and as is common knowledge, this is largely due to the fact that platforms generally oppose regulation. Government authorities and the legislative branch are thus attempting various ways of overcoming this resistance, as shown below.

To recapitulate, evidence suggests that Latin American labour market tendencies extend to digital platform work, although more precise studies are needed to corroborate this. This would entail improving available statistical sources and considering the inclusion of emerging occupations in the digital economy in national surveys of occupation and employment. On the other hand, the high levels of satisfaction, flexible hours and income level of workers on digital platforms need to be considered when designing labour regulations. As will be seen, this is a highly contentious issue. Nevertheless, these opinions also show that much still needs to be done in order for both platforms 
and workers to appreciate that flexibility for workers does not necessarily need to imply a lack of labour rights, as correctly expressed by the OECD (2019). Without a doubt, there are many reasons workers may be satisfied with their situation, especially when comparing it with that of the many poorer-quality jobs available within a context of low economic growth. Nevertheless, this should not relegate the discussion regarding regulatory alternatives to a secondary question or one without justification, as argued by the platforms.

\section{3 \\ REGULATING THE PLATFORM ECONOMY: WHY AND HOW}

It is worth mentioning that the lack of employment formalization in Latin American countries is critical, because, as mentioned above, there is no universal social security system independent of employment status. The debate around this issue reveals various positions regarding the regulation of digital work; specifically, whether it should be regulated, and if so, how. Two key questions emerge: the heterogeneity of platforms (are they true service providers or simply technological intermediaries), and the nature of the relationship between platforms and their service providers (are workers self-employed or subordinate). However, while there is consensus regarding the need to prevent digital platform work from expanding the 'cycle of poor-quality jobs' (BID 2015) and aggravating existing labour market tendencies, a variety of theoretical perspectives exist regarding how to approach this, and what the rationale and scope of state intervention should be. Equally, a range of positions question the capacity and interest of unions to defend platform workers, as well as the willingness of these workers to organize.

The nature of digital platforms and the social connections between them and their service providers are at the centre of the debate around the need to regulate, and more importantly, around what instruments the state should use in order to do this (Rodríguez-Piñero 2018).

Another debate in relation to digital platforms revolves around to what extent the economy and social relations could be platformized. There are two perspectives with regards to this issue. On the one hand, it is argued that the digital platforms with their particular business models and algorithmic management drastically reduce the transactional costs of economic and social exchanges. As a consequence, a new managerial rationality emerges from the intensive use of algorithms, replacing human managers. Thus, traditional companies will tend to adopt a business and managerial model comparable to that used by digital platforms (Kilpi 2015, cited in Degryse 2019). From the other perspective, critical of the former, it is asserted that the digital platforms have developed a narrative which legitimates their status as technological intermediaries between an autonomous worker and a customer who requires 
a particular service. In other words, the platforms' narrative conceals their condition of being companies that provide services, while their actions reveal that, in fact, they are. This would imply that there is a shift in business narratives rather than a change in practices as a result of digital technology (Tomasseti 2016, cited in Degryse 2019).

Other areas of debate centre around whether these platforms generate new forms of job insecurity or simply reproduce existing insecurity (CEPAL-OIT 2019). It is worth asking whether existing labour institutions that protect subordinate work are still useful or if new mechanisms of inclusion are needed (OIT 2019b).

A particular feature of the platforms is that they take advantage of intermediate technologies for the organization and management of work in traditional sectors such as transportation, domestic work, courier services, food delivery services and even professional activities. Those who argue that platform work reflects a continuity in the nature of work, rather than a rupture, maintain that digital workers have more in common with traditional agricultural labourers or domestic workers in the region (CEPAL-OIT 2019). While it may be true that platforms facilitate the reproduction of traditional informality and insecurity with a new face, technology can also be used as a tool to monitor and neutralize negative aspects, such as the evasion of tax and employer responsibilities. Workers could also make use of these platforms to establish flexible forms of organization and networks, which could, to some degree, counterbalance the isolation they may experience in their work. The obstacle of isolation acquires particular importance for workers on platforms such as Uber, Cabify or Didi. This is due to the fact that these workers do not share any space facilitating face-to-face gatherings which would enable them to establish social bonds around their work, something that delivery workers for Rappi have established in their interactions outside restaurants. Personal interaction is a key factor for the emergence of collective action, as it has an impact on the construction of a shared identity (Haidar et al. 2020).

\subsection{The Heterogeneous Nature of the Platforms and the Scope of their Operations}

Given its heterogeneity, there is no single answer regarding what to do in the face of the expanding platform economy. For example, platforms offer services which may be performed virtually or face to face; some offer specific services, while others have a wide range of services, and the scope of their operations are both national and international (Todolí 2017). Furthermore, there are also differences in the level of qualifications needed in order to offer services (Drahokoupil and Fabo 2016). Nevertheless, the most salient characteristic in deciding on regulation is whether locally implemented platforms 
operate exclusively as technological intermediaries, or if they organize service providers, as will be discussed below.

The purpose of all digital platforms, despite their diversity, is to be a technological intermediary in online space, between the supply and demand for a particular service. This is done through the use of algorithms and an interface (app) on which service users can register and connect with suppliers (Todolí 2017). However, it has been found that not all limit their functions to technological intermediation, but also assume other functions, which would equate them with service provider companies.

According to Goerlich and García (2018), a platform is considered to be a service-providing company when it unilaterally designs the characteristics of a service and organizes and establishes the conditions under which the service is provided. Another feature of these platforms is that they assume control and supervision of the provision of services through some form of evaluation. Furthermore, platforms are considered to be service providers when they fix the cost of the service, as would be done by the key asset owner (CEPAL-OIT 2019). On the other hand, if the price is determined by the service provider, it is agreed upon with the client, and if the provider designs and determines the service, the platform is considered to be an intermediary.

The classification of platforms as service providers or as technological intermediaries is only the starting point in establishing whether the relationship between platforms and workers is of a subordinated nature. Although service provider platforms tend to forge subordinated relationships with their workers, this does not necessarily result in them legally recognizing their responsibilities as employers. On the other hand, the characterization of platforms as solely technological intermediaries also does not rule out all employment responsibilities in relation to their service providers (Goerlich and García 2018).

\subsection{Employer Evasion and the Commodification of Labour}

Regardless of the classification of platforms, there is consensus that in reality they are business models that avoid labour protection for paid work. Degryse (2019, p. 28) considers this 'the organized irresponsibility of companies to disappear the figure of an employer, deny labour relations and make collective agreements inapplicable'. From this point of view, the consequence of the expansion of the platform economy is the abandonment of social-labour relations developed in conventional companies, legitimized, in theory, by the opportunities for flexibility offered by the platforms. According to this approach, one of the main problems of platform work is the commodification of labour relations though adhesion contracts (hiring agreements) that may define false self-employment, i.e. that may conceal subordinate employment relationships. This is because they are contracts the clauses of which are 
unilaterally defined by the digital platforms, in which any indication that could provide justification for considering these workers as subordinate to the platforms is excluded, even when in practice they maintain control over and supervise the work (for the case of Mexico see Bensusán 2020).

In sum, according to Degryse (2019), what is of concern regarding work on digital platforms and the fourth industrial revolution is not the end of work, but rather the possibility that employers will begin to evade their responsibilities by hiding behind technology and the commodification of labour.

In this respect, both Latin America and the rest of the world face two key challenges. The first is to differentiate between platforms that limit their activities to technological intermediation and those that broaden their operations to include the provision of services. This first step in identifying subordinate working relationships is important as it avoids locating the heterogeneity of platforms within homogenous regulatory schemes. The second challenge is to identify the employers in order to avoid the negative social and employment consequences of them hiding behind technology and the heterogeneity of these businesses (Degryse 2019; Rodríguez-Piñero 2016). In sum, it is necessary to establish the responsibility that digital platforms have towards their workers. This will largely depend on whether traditional attributes of subordinate labour apply, and whether these criteria should be made more flexible as the nature of work transforms with new technology and business models. This will be addressed in the next section.

\subsection{The Role of the State}

As stated in the introduction, there are various perspectives on the role of the state in a digital economy characterized by the heterogeneity of platforms and uncertainty regarding their legal nature and the way in which they should be regulated. A first, and among the most optimistic theoretical approaches, was proposed by Arun Sundararajan (2017), who indicates that rather than intervene in the regulation of what he refers to as 'platform capitalism', the state should restrict itself to collaborating with and delegating regulatory responsibility to the platforms themselves, their workers, civil society organizations, consumers and other stakeholders. His proposal consists of generating digital trust networks that self-regulate through a certification granted to the platforms by the government and civil society organizations and the clear definition of the faculties of all involved parties. However, the author himself recognizes that emerging self-regulation by digital trust networks can be complemented by the state. Given the tendency to substitute subordinate work for self-employment, he suggests that new social contracts and models of regulation are required in which protections and rights can be transferred when workers move from one platform to another. Such a contract would have a universal reach and 
thus would be linked to citizenship and not employment. As we shall see, this proposal has generated significant support.

Based on a political economy approach, Rogers (2016) argues that the dichotomy between dependent and independent work needs to be overcome, founded on the principles of a democratic political order. In his view, the whole labour force should be guaranteed rights and civil liberties, individual dignity and distributive justice regardless of employment status. In this case, while the criteria commonly used to identify legal or economic dependence would indicate whether a worker is in a subordinate relationship with their employer, they should not necessarily determine the employment status. He proposes returning to the basic sense of rights and labour regulations - to reduce asymmetries - which would enable 'fomenting a more egalitarian and democratic political economy’ (ibid., p. 483).

Rodríguez-Piñero (2016) offers another approach by arguing that the digital platform economy is in a pre-regulatory stage in which uncertainty prevails regarding the categorization of work on platforms (in part due to contradictory judicial rulings) and the scarcity of legislative activity to regulate it. This perspective poses the question of how to reformulate regulations across various legal systems - labour, fiscal, administrative and competence - in order to deal with the issues raised by digital platforms. This task would entail confronting at least four challenges: dealing with situations of illegality; resolving legal uncertainty in the classification of workers; adopting means of protection for genuinely self-employed workers; and moving from bilateral labour models to multilateral models.

\subsection{Proposals for Public Intervention}

Even among proposals that agree on the need for state intervention into the platform economy, different approaches exist. The first is to create a universal employment relationship (Countouris 2019). This proposal is particularly important in countries where access to social security is currently conditioned upon a subordinate employment relationship, as is the case in Latin American countries. A universal employment relationship would extend currently legislated labour rights to all workers, independent of their legal status. In other words, this would entail the dominance of fact over form as the general criterion to access labour rights. Thus, many of the employment relationships currently located in labour market grey areas, due to informality, poor classification, or because they do not strictly fulfil the characteristics of a subordinate employment relationship, would still be covered by social protection.

Another proposal from the ILO (OIT 2019b) centres around people. Informed by this principle, state intervention should aim to promote people's capabilities and strengthen labour institutions and programmes that incentivize 
decent work. The singularity and merit of this proposal lies in the fact that it argues for the need for global labour governance for platforms. In addition, it also highlights the need to establish legal responsibility for companies using algorithms to organize work. It coincides with previous proposals by focusing social protection on people, independently of how their occupation is contractually characterized.

Similarly, the OECD (2019) argues that while new forms of work can provide companies and workers with high degrees of flexibility, this should not result in job insecurity and the weakening of labour and social protections for workers. This position is reflected in the seven areas of social protection proposed by the OECD. In contrast to the previous two proposals, the OECD does not argue for the universality of social protection, although it does emphasize the need to strengthen it, including the creation of intermediate categories of work.

\subsection{Collective Actors: Perspectives and Experiences}

One commonly agreed upon aspect is the importance of collective bargaining with digital platforms in order to secure the protection of workers' rights. This brings us to the issue of collective action on digital platforms. Hyman (2015) argues that given the tendency towards job insecurity, including work on digital platforms, limits need to be placed by either the political elite or by unions who have played a historical role in counteracting inequality. In response, contrasting views exist, both optimistic, related to studies of union revitalization (Murray 2016), as well as pessimistic, viewing unions as actors with exclusively economic interests whose sole focus is the interests of their members (Standing 2011). As such, if unions are to assume their role as principal actors in the struggle against poverty and inequality and to protect the most vulnerable, they will need to change their traditional forms of organization for less hierarchical ones, return power to their rank and file and link affiliation to individuals, who would thereby be able to maintain their membership regardless of occupation (Hyman 2015; Hayter and Stoevska 2011). Without a doubt, technology could be an indispensable tool for overcoming obstacles and countering isolation, even though these conditions did not impede the organization of others in similar situations, such as agricultural or domestic workers. However, the relationships of organizations with their rank and file members, political parties, the state and civil society are embedded in socio-political and institutional configurations. These factors can obstruct, facilitate or, under exceptional circumstances, remain neutral in the face of union transformation.

It is thus imperative to consider the broad institutional environment and labour laws in each country as they shape what unions are, what they do, the 
organizational problems they face, as well as workers' expectations and decisions regarding affiliation and participation (Godard 2008).

Given the different socio-political and institutional configurations, union cultures and trajectories, as well as the varied relationships with the state in the region, the opportunities for and limitations on collective action vary substantially. These range from state corporativism less inclined to opening up to other movements or new categories of workers (Argentina and Mexico), to corporativism of a more social nature, which maintains broad alliances with social movements and seeks the affiliation of workers affected by the insecurity of working and living conditions, such as in Uruguay and Brazil (Bensusán 2019). Thus, while in some countries it can be expected that the state (executive, legislative and/or judicial branches) will spearhead efforts to halt job insecurity, in others the leading role could be played by collective organizations.

Either way, for workers in the digital economy, a first step is ensuring access to the full enjoyment of collective rights. However, this is not a sufficient condition for platform workers to organize and negotiate collectively with platforms. On the contrary, various factors explain the slow progress in organizing digital platform workers, not only in the region.

First, collective action for digital workers needs to be based more on solidarity than on a shared identity given the heterogeneous or temporary nature of their activities, even though the experience of Argentinian workers shows that the construction of an identity is possible and politically productive (Haidar et al. 2020). Evidence shows that many workers are not aggrieved by their lack of recognized labour rights and may even express satisfaction with the conditions of this type of work. Second, platforms are reluctant to recognize themselves as employers. Third, the work is isolated, generating individualistic behaviours that may hinder - though not prevent - opportunities for collective action, as they inhibit an understanding that organizing may be a path towards countering the insecurity associated with the lack of rights (Díaz Santana 2020).

Finally, as has already been mentioned, the idea that the flexibility that workers enjoy is not compatible with access to rights, hampers organizing efforts. Nevertheless, some evidence indicates that interest in collective action and the formation of unions also varies according to the type of platform. For example, deliverers of food and other merchandise show a greater disposition to organize than workers in private passenger transport platforms (Bensusán 2020). Without a doubt, information regarding impediments to collective action, and particularly on variations by country, type of platform and activities, is still relatively scarce and further research is required.

One experience of organization and collective action ${ }^{6}$ is provided by APP (the Association of Platform Workers), founded in 2018 in Argentina by organized workers on the Rappi platform. Haidar et al. (2020) analyse the case 
from the perspective of workers' resources of power. They examine an action which they describe as being similar to a strike, organized through WhatsApp communities, and conclude that an essential factor in its success was the face-to-face gatherings of workers outside the businesses while they waited for work. These gatherings play a crucial role in overcoming the workers' lack of power in the labour market. It is important to note that these workers constructed a collective identity on the basis of discovering shared interests, and transforming them into demands such as the legal recognition of their subordinate employment relation with their employer (Rappi) and access to labour rights.

This process involved transforming the delivery workers' perception of themselves as self-employed and constructing a workers' identity. The organized workers also drew on resources such as discursive power, challenging the company's image and hoping that public opinion would pressure the platform into conceding to the workers' demands. Another resource of power they harnessed, although not without difficulties, was the formation of coalitions with pre-existing union organizations (Haidar et al. 2020). This experience shows that the platforms' algorithmic management generates a dual movement: it is the source of labour grievances, but at the same time it opens up the possibility of converting these grievances into politically productive actions through a key actor in the world of digital work - the unions.

\section{LATIN AMERICA IN THE INTERNATIONAL CONTEXT: VARIATIONS IN PROTECTION}

The theoretical approaches mentioned above identify various paths and orientations of state intervention in the digital economy. The different alternatives for intervention also reflect the political orientation of governments regarding the protective or liberal role they choose to play in labour relations. However, in Latin America, low taxation and poor tax collection capacity severely limit the ability of governments to implement what is generally considered to be one of the best methods of avoiding exclusion from social protection - the adoption of universal social security systems, which would include the whole population regardless of employment relations. This possibility remains pending, and lacks any substantial progress, even by governments with a left-leaning political ideology (Reygadas and Filgueiras 2011).

\subsection{The Role of Labour Judges: Method of Indicators ${ }^{7}$ and Legal Interpretation}

Given minimal legislative progress and the obstacles to moving towards universal social security, judicial interpretation - a traditional but expensive 
method for distinguishing between subordinate work and self-employment - has been the main way of determining access to rights for platform-based workers (Sánchez-Urán 2018). However, this method depends on an initial demand from workers and generates significant uncertainty, as the legal interpretation of classification criteria may vary within a single country for similar cases, as will be shown in the cases of Spain, the United States and Argentina (Bensusán 2020). Thus, many propose a legislative path, though this would also be subject to the same issue of legally interpreted criteria.

On an international level, judges use traditional criteria (Table 10.1) to classify the nature of work on digital platforms. One of the variants in their deliberations is the rigidity or flexibility with which they interpret these criteria, as rulings tend to use different combinations of the indicators in Table 10.1. We refer here generically to the indicators of dependence and independence as it is beyond the scope of this chapter to detail all these combinations. While the particularities of each ruling may be lost, we nevertheless show the interpretative variation of the indicators.

Table 10.1 Indicators of subordination or independence on digital platforms

\begin{tabular}{l|l}
\hline Dependence and subordination & Autonomy/Independence \\
\hline Power of direction, control and discipline & a) Time and place of work freely chosen by the worker \\
$\begin{array}{ll}\text { a) Disconnection from the platform (dismissal) } & \text { b) Power to reject services } \\
\text { b) Systems of evaluation } & \text { c) Contact with the market } \\
\text { c) Work guidelines } & \text { d) Assume business risk } \\
\text { d) Contracts of services/commercial contracts } & \text { e) Agree work guidelines } \\
\text { unilaterally developed by the platform } & \text { f) No exclusiveness } \\
\text { Necessary and sufficient conditions } & \text { g) Secondary activity } \\
\text { e) Recruitment processes and selection of } & \\
\text { workers } & \\
\text { f) Cannot deny services } & \\
\text { g) Price setting by platform } & \\
\text { h) Platform owns assets } & \\
\text { i) Remuneration and personal nature of work } & \\
\text { j) Exclusiveness } & \\
\text { k) Place and time of work } & \\
\text { 1) Training } & \\
\text { m) Use of logos }\end{array}$
\end{tabular}

Source: Adapted from Bensusán (2020, p. 19).

Contrasting interpretations are a source of uncertainty. According to judicial rulings emitted in Valencia $^{8}$ in 2018 (Deliveroo) and in Madrid ${ }^{9}$ in 2019 (Glovo), an employment relationship was recognized between the platforms 
and its delivery workers. The first case was based on the principle of the primacy of facts (in light of the indicators of dependence and subordination) regarding the way in which the involved parties described their relationship. In contrast, the ruling in Madrid offered a new interpretation of the indicator of 'workplace', understanding it as 'all that can be the object of geolocalization' and that of 'working time' as 'all that in which the activity can be realised using ICT'. However, contrary to the above, another court in Madrid ${ }^{10}$ in 2019 ruled that the relationship between Glovo and one of its deliverers was of a commercial nature, and the worker was thus considered to be independent of their employer. In this case, the judge argued, taking a stringent approach, that indicators of dependence did not apply.

Another illustrative case comes from the United States. In 2018, a judge in Pennsylvania (BCNC 2018) applied the 'Donovan Factors' test, which, with some variation, endorses the indicators of dependence/subordination presented in Table 10.1. The judge found that as Uber did not control nor direct drivers, no employment relationship existed between the platform and the driver. In contrast, in 2018, a judge in New York (Van den Bergh 2019), taking into consideration some of the indicators of dependence and subordination, ruled that Uber exercised control over its workers and, consequently, their relationship was of an employment nature. One of the arguments in the ruling was that indicators needed to be loosely interpreted, given that labour relations evolve over time and thus need to be considered in context.

In the Latin American context, at least two rulings, one in Uruguay ${ }^{11}$ (2019) and the other in Brazil ${ }^{12}$ (2017) recognized the dependent and subordinate character of the relationship between Uber and plaintiff drivers, subscribing to the primacy of fact over form based on the criterion from the control that Uber exercises over its drivers. Regarding more general arguments, the judge in Brazil maintained that platforms represent a new type of employer, and that the employment relationship presents new characteristics that need to be taken into account in order to protect workers. For its part, the Uruguayan ruling emphasized that work should be seen as a 'social, dynamic, changing and evolving fact [ $\ldots$ with] new ways of organizing work, taking advantage of new technologies', to which legal procedures needed to adapt.

Contradictory interpretations are also evident in Argentina regarding the nature of work on digital platforms. The Federal Administration of Public Income (AFIP) regards Uber as the type of business anticipated in the Employment Contract Law, and thus argues that it should fulfil its tax and social security obligations. However, criminal law rulings (economic, conventional and misdemeanours) found that Uber was limited to intermediating the supply and demand of transport and thus its workers are self-employed ( $\mathrm{La}$ Nación 2019). 
In sum, specialists (Rodríguez-Piñero 2016, 2018; Pérez de los Cobos 2018; Sánchez-Urán 2018) tend to agree that legal uncertainty in the platform economy is the result of a diversity of interpretations of the indicators of independence and subordination, even regarding the same platform. In the face of such uncertainty, the role of legislators is fundamental.

\subsection{The Incipient Role of Employment Legislation}

Upon reviewing international labour legislation, at least three countries were found with laws regulating platform work: France (Daugareilh 2019), the regions of Lazio and Piamonte in Italy (Borelli 2019), and the state of California in the USA (Solís 2019; BCNC 2018). In the French case, platform workers are considered to be self-employed, although they do have access to social security, as is the case in the other two countries. In Italy, legislation classifies work on all platforms as subordinate and dependent, while in the US case, labour laws are limited to drivers on transport platforms.

Two countries recognize intermediate work categories in their employment legislation, although these were not specifically designed for work on digital platforms. In England, the equivalent category is 'dependent contractor' or 'worker' (Mason 2019), while the Italian concept is of 'para-subordinate' workers (Borelli 2019). With their respective variations regarding the indicators that substantiate this third category, all provide limited rights to workers. The literature discusses the degree to which these categories are viable for platform work.

The Mexico case illustrates how, within a context of union weakness or disinterest following decades of neo-liberal policies, a change in government political orientation following the 2018 elections resulted in a greater top-down demand to protect vulnerable groups in the labour market. ${ }^{13}$ Mexican legislative initiatives concerning both labour regulations (not passed) as well as tax regulations (passed) are signs of a new phase of legislative activism that may favour platform workers.

Although still to be approved, Mexico has two legislative initiatives (Alemán 2019; Padilla 2019) and Colombia has one (Lara 2018) that aim to regulate work on digital platforms. The main difference between them relates to the recognition of a subordinate work relationship between platforms and workers in the Mexican case and the categorization of this work as self-employment in Colombia. These initiatives thus differ regarding the obligations of the platforms and the rights of workers.

Despite these differences, a central concern of both countries' initiatives is access to social security. A key difference is that in Colombia, contribution payments for social security are equally divided between platforms and workers, while in Mexico, by recognizing workers on platforms as subordinate 
and thus granting them full rights as established in the labour law, contributions are paid by employers, workers and the state. One of the shortcomings of the Mexican initiatives is that they do not specify the indicators needed to recognize platform workers as subordinate, which are necessary in order to confront the uncertainty of the legal classification of these occupations. In contrast, the Colombian initiative includes specific criteria for the proposed intermediate employment category for platform work.

\subsection{Other Regulations}

Interest in regulating platforms goes beyond concerns related to labour rights and has increasingly adopted a restrictive, if not prohibitive, nature. Various Latin American countries have already reformed their tax schemes or have reform initiatives underway regarding the Value Added Tax (VAT) for digital economy activities with rates that vary between 9 per cent and 22 per cent, depending on the country (Chile, Costa Rica, Uruguay, Colombia, Argentina and Mexico) (CEPAL 2019). With their own individual characteristics, each country has included mechanisms to ensure the effective levying of VAT in their reforms. For example, Argentina identifies the cell-phone code from which a service is requested as the mechanism for detecting and levying VAT. In Mexico workers are obliged to request that the platforms provide them with proof of tax contributions from their income.

In Peru and Uruguay, the tax schemes related to income tax have been modified to include digital services. In 2003, Peru legally established that platforms' income should be levied for income tax at a rate of 30 per cent (CEPAL 2019, p. 76). In 2017, Uruguay established a law that levied the total income obtained by digital platforms at a rate of 12 per cent (CEPAL 2019). In contrast to these two countries, where the income of the platforms is taxed, in Mexico the current scheme for levying income tax in the platform economy applies to workers' income.

An alternative way to regulate digital platforms has been at a sectoral level as, for example, with the private transport platforms in Mexico City. This strategy assumes that these platforms overlap with the traditional industry of regulated taxis, reshaping the sector. For example, taxi drivers must comply with certain administrative regulations, and assume economic costs in order to provide transport services, which is not the case with digital platforms. This legal inequality has led to an inter-sectoral dispute between taxis and transport platforms around the inequality of conditions of competition between sectors. Another inter-sectoral disparity relates to the tax obligations of taxis and Uber. The latter is obligated to retain taxes from its drivers and declare to the tax authorities, while taxi concession holders are not. On the other hand, the 
generalized labour informality of taxi drivers (Pogliaghi 2012) overlaps with that of Uber drivers (Hernández and Galindo 2016).

Regulating on a sectoral level has the advantage of countering the heterogeneity of digital platforms and is an alternative consistent with Rodríguez-Piñero's (2016) argument that the platform economy requires the reorganization of various legal fields (Santos 2020).

\section{CONCLUSIONS}

In the face of the expansion of digital platforms, the challenge is how to formalize the jobs generated by these without affecting the benefits that they offer workers, particularly given the limited or null economic and formal employment growth in the region. These benefits include minimal entry barriers and a degree of work flexibility.

In this chapter we have argued that the quality of work generated by digital platforms will depend both on their characteristics as well as on the opportunities and restrictions faced by states and social actors (primarily unions) to regulate the platforms and to counteract the unilaterality of their actions. The debate around protection is far from settled and while Latin America may have been slow to respond, various countries are now responding to the challenge, through either legislation or legal interpretations, in order to relax the criteria for categorizing work as subordinate employment and enable workers to claim their rights. Overcoming the uncertainty that currently characterizes employment relations with the platforms is imperative in order to avoid the spread of informality, job insecurity and inequalities in the labour market.

As has been shown in this chapter, in the face of the profound transformations experienced in these markets, and the increasing urgency to promote a transition to models of social incorporation that do not depend on the nature of employment status, two types of problems exist. On one hand, there is the issue of financing, and on the other, the risk of weakening the protection of subordinate work - by decreasing rights - for the sake of extending this to all workers, encouraging employers to evade their employment responsibilities.

Although platform workers themselves may be somewhat satisfied with their working conditions and convinced of the advantages of this type of work over others, this should not legitimize the position of platforms, which resist assuming their responsibilities and successfully disseminate the argument that flexibility necessarily correlates with the absence of rights. It is up to the state, the unions and society in general to reject this, as well as to find the best way of protecting workers without ignoring the importance of platforms as sources of employment nor nullifying the advantages derived from their lower entry barriers. 


\section{NOTES}

1. An extended version of the content of this chapter can be found in Bensusán (2020). Also included are some of the findings from research conducted by Santos (2020) as part of his master's thesis (Instituto de Investigaciones Dr. José María Luis Mora) funded by a scholarship from the National Council for Science and Technology.

2. All digital platforms offer their services through the internet. The difference lies in how the services are performed: 'online' being without the physical presence of the person providing the service, and 'offline' with (Todolí 2017).

3. Uber announced that from 1 February 2020 it would withdraw from Colombia as a consequence of the judicial ruling which ordered the company to suspend its operations in the country, which indicated that Uber had failed to comply with the existing competency regulations (Cuevas 2020). However, in July 2020 Uber obtained a ruling in its favour from the Supreme Court in Bogotá, enabling its return (Torres Reina 2020).

4. See the INEGI glossary at https://www.inegi.org.mx/app/glosario/default.html?p= ENOE15 (accessed on 7 June 2020).

5. Twenty-two interviews were conducted with various actors, including Uber drivers, and 20 questionnaires were completed by Rappi workers between August and October 2019. See Bensusán (2020).

6. Other experiences developed in Mexico with the Independent Union of App Delivery Workers SIRA APPS (legally a coalition according to articles 354 add 355 of the Federal Labour Law), and in Chile with the Chilean Union of Uber Drivers.

7. This consists of judges assessing the facts of a particular employment situation by interpreting a set of legal indicators that determine their legal nature.

8. $\quad$ Ruling No. 6/244, Juzgado no. 6 de Valencia no. 244, 1 June 2018.

9. Ruling No. 53/19 [Glovo], Juzgado de lo Social No. 33 de Madrid, Spain.

10. Ruling No. 715/2019 [Glovo], Tribunal Superior de Justicia de Madrid Sección 04 de los Social, Spain.

11. Ruling No. 77 Montevideo. C/UBER TECHNOLOGIES URUGUAY S.A. Y OTRO. PROCESOLABORAL ORDINARIO (LEY 18.572). Sheet 2-3894/2019.

12. Ruling passed in case 0011359-34.2016.5.03.0112 [Uber], 33 Juzgado del Trabajo de Belo Horizonte, Brazil.

13. In addition to significant increases to the minimum wage in December 2018 and 2019, reforms were passed aimed at protecting workers in matters related to freedom of association, labour law and domestic work. There are also initiatives to restrict outsourcing and protect telework (Bensusán 2020).

\section{REFERENCES}

Alemán, M. C. (2019), 'Iniciativa que reforma diversas disposiciones de la Constitución Política de los Estados Unidos Mexicanos; y de las leyes del Impuesto Sobre la Renta, y Federal del Trabajo a cargo de la Diputada María Alemán Muñoz Castillo' (grupo parlamentario del PRI), México: Cámara de Diputados LXIV Legislatura.

Azuara, O., S. González and L. Keller (2019), ‘¿Quiénes son los conductores que utiliza las plataformas de transporte en América Latina?, Perfil de los conductores de Uber 
en Brasil, Chile, Colombia y México', Washington DC: División de Mercados Laborales del Banco Interamericano de Desarrollo.

BCNC (Biblioteca del Congreso Nacional del Chile) (2018), 'Uber y conductores. Legislación comparada sobre la relación laboral, Asesoría Técnica Parlamentaria', accessed 10 October 2019 at https://www.bcn.cl/obtienearchivo?id=repositorio/ 10221/25909/2/BCN_Uber_laboral_actualizado_PA_CW_GW_2_.docx

Bensusán, G. (2019), 'Trade unions and politics in Latin America', in Harry E. Vanden and Gary Prevost (eds), Encyclopedia of Latin American politics, Oxford: Oxford University Press.

Bensusán, G. (2020), 'Ocupaciones emergentes en la economía digital y su regulación en México', Serie Macroeconomía del Desarrollo, Santiago: Comisión Económica para América Latina y El Caribe (CEPAL).

Berg, J. and V. De Stefano (2016), '¿Se quiere mejorar el crowdwork? Entonces hay que regularlo', Global Labour Column, 240, 3.

BID (Banco Interamericano de Desarrollo) (2015), 'Empleos para crecer', Washington DC: Banco Interamericano de Desarrollo.

Borelli, S. (2019), 'Italy', in Isabelle Daugareilh, Christophe Degryse and Philippe Pocher (eds), The platform economy and social law: Key issues in comparative perspective, Brussels: European Trade Union Institute (ETUI).

Buenadicha, C., A. Cañigueral and I. De León (2017), 'Retos y posibilidades de la economía colaborativa en América Latina y el Caribe', División de competitividad, tecnología e innovación, Washington, DC: Banco Interamericano de Desarrollo.

CEPAL (Comisión Económica para América Latina y el Caribe) (2010), 'La hora de la igualdad: brechas por cerras, caminos por abrir', Brasilia del 30 de mayo a 1 de junio de 2010, Santiago, Chile.

CEPAL (Comisión Económica para América Latina y el Caribe) (2019), 'Panorama Fiscal de América Latina y el Caribe 2019: políticas tributarias para la movilización de recursos en el marco de la Agenda 2030 para el Desarrollo Sostenible', Santiago, Chile.

CEPAL-OIT (Comisión Económica para América Latina y el Caribe) Organización Internacional de Trabajo) (2019), 'El futuro del trabajo en América Latina y el Caribe: antiguas y nuevas formas de empleo y los desafíos para la regulación laboral', Coyuntura Laboral en América Latina y el Caribe, 20, mayo de 2019, Santiago, Chile.

CONEVAL (Consejo Nacional de Evaluación de la Política de Desarrollo Social) (2018), Estudio diagnóstico del derecho al trabajo 2018, México: CONEVAL.

Countouris, N. (2019), Defining and regulating work relations for the future of work, Geneva: International Labour Organization.

Cuevas, S. (2020), 'Uber anuncia su salida de Colombia, luego de orden para suspender operaciones', accessed 10 January 2020 at https://www.elfinanciero.com.mx/tech/ uber-se-va-de-colombia-a-partir-del-1-de-febrero

Daugareilh, I. (2019), 'France', in Isabelle Daugareilh, Christophe Degryse and Philippe Pocher (eds), The platform economy and social law: Key issues in comparative perspective, Brussels: European Trade Union Institute (ETUI).

Degryse, C. (2019), 'Introduction', in Isabelle Daugareilh, Christophe Degryse and Philippe Pochet (eds), The platform economy and social law: Key issues in comparative perspective, Brussels: European Trade Union Institute (ETUI).

Díaz Santana, M. (2020), Trabajo en plataformas digitales: Estado y acción colectiva, Tesis de Doctorado [borrador], México: Flacso-México. 
Drahokoupil, J. and B. Fabo (2016), 'The platform economy and the disruption of the employment relationship', Policy Brief No. 5 European Economic, Employment and Social Policy, Brussels: European Trade Union Institute (ETUI).

Eisenmeier, S. (2018), 'The contradictory effect of on-demand ridesharing on labour: The cause of Uber in Mexico City', paper presented at Seminario de la Ciudad de Mexico: Pasado y Presente, Instituto Mora, June 2018.

Godard, J. (2008), 'Union formation', in Paul Blyton, Nicolas Bacon, Jack Fiorito and Edmund Heery (eds), The Sage handbook of industrial relations, Thousand Oaks, CA: SAGE Publishing.

Goerlich, J. M. and M. A. García (2018), 'Indicios de autonomía y laboralidad en los servicios de los trabajadores de plataforma', in Francisco Pérez de los Cobos (Dir.), El trabajo en plataformas digitales. Análisis sobre su situación jurídica y regulación futura, España: Wolters Kluwer.

Haidar, J., N. Diana-Menéndez and C. Arias (2020), 'De la app a la APP. La gestión algorítmica y los procesos de organización y lucha de los trabajadores de reparto', in Héctor García y Lucas Caparrós (comps.), El trabajo en la economía de plataformas, Buenos Aires: EDIAR.

Hayter, S. and V. Stoevska (2011), Social dialogue indicators, international statistical inquiry 2008-09, Geneva: International Labour Organization.

Hernández, Y. and R. Galindo (2016), 'Modelo de gestión del servicio de transporte UBER ¿Quién pierde y quién gana?', Revista Estudios Públicos, 19 (47), 147-175.

Hyman, R. (2015), 'Tres hipótesis sobre el futuro de las relaciones laborales en Europa', Revista Internacional del Trabajo, 134 (1), 5-15.

ILO (International Labour Office) (2020), Global employment trends for youth 2020: Technology and the future of jobs, Geneva: ILO.

La Nación (2019), La AFIP determinó que Uber debe $\$ 358$ millones en tributos $y$ cargas sociales, accessed 20 October 2019 at https://www.lanacion.com.ar/ economia/deuda-millonaria-la-afip-determino-uber-debe-nid 2242513

Lara, R. (2018), Proyecto de ley número 082 de 2018 Cámara, por medio de la cual se regula el Trabajo Digital en Colombia y se dictan otras disposiciones, accessed 5 september 2019 at https://congresovisible.uniandes.edu.co/proyectos-de-ley/por -medio-de-la-cual/9526/\#tab=2

Madariaga, J., C. Buenadicha, E. Molina and C. Ernst (2019), Economía de plataformas y empleo. ¿Cómo es trabajar en una APP en Argentina?, Buenos Aires: CIPPEC, BID, OIT.

Mason, L. (2019), 'United Kingdom', in Isabelle Daugareilh, Christophe Degryse and Philippe Pocher (eds), The platform economy and social law: Key issues in comparative perspective, Brussels: European Trade Union Institute (ETUI).

Murray, G. (2016), 'Union renewal: What can we learn from three decades of research?', Transfer: European Review of Labour and Research, 23 (1), 9-29.

OECD (Organisation for Economic Co-operation and Development) (2019), 'Policy responses to new forms of work', paper prepared for the second meeting of the G20 Employment Working Group under the Japanese G20 Presidency in Tokyo, 22-24 April 2019.

OIT (Oficina Internacional del Trabajo) (2015), Trabajar para un futuro más prometedor. Comisión Mundial sobre el Futuro del Trabajo, Ginebra: OIT.

OIT (Organización Internacional del Trabajo) (2018), Panorama Temático Laboral. Presente y Futuro de la Protección Social en América Latina y El Caribe, Lima: Oficina Regional para América Latina y El Caribe. 
OIT (Organización Internacional del Trabajo) (2019a), Panorama Laboral 2019, América Latina y el Caribe, Lima: OIT, Oficina Regional para América Latina y el Caribe.

OIT (Organización Internacional del Trabajo) (2019b), Trabajar para un futuro más prometedor, Ginebra: Comisión Mundial sobre el Futuro del Trabajo.

Padilla, J. (2019), Iniciativa por la que se reforma la ley federal del trabajo para regular a los trabajadores de las empresas de servicios por medio de aplicaciones digitales (Grupo Parlamentario del Partido del Trabajo), México: Senado de la República.

Pérez de los Cobos, F. (dir.) (2018), El trabajo en plataformas digitales. Análisis sobre su situación jurídica y regulación futura, España: Wolters Kluwer.

Perry, G., W. Maloney, O. Arias, P. Fajnzylber, A. Mason, J. Saavedra-Chanduvi and M. Bosch (2007), Informalidad: escape y exclusión, estudios del Banco Mundial sobre América Latina y el Caribe, Washington, DC: Banco Mundial.

Pogliaghi, L. (2012), 'La problemática del trabajo, la identidad y la organización colectiva en los taxistas de la ciudad de México', in Enrique De La Garza Toledo (coord.), Trabajo no clásico, organización y acción colectiva, México: UAM-I/ Plaza y Valdés Editores, pp. 209-250.

Reygadas, L. and F. Filgueiras (2011), 'Desigualdad y crisis de incorporación: la caja de herramientas de políticas sociales de la izquierda', in Gonzalo Abad Ortiz (coord.), América Latina y el Caribe: Escenarios posibles y politicas sociales, Montevideo: Flacso/Editor Theutonio Dos santos, pp. 133-160.

Robinson, W. (2015), 'Can digital sharing economy platforms pull Latin America's informal sector into the mainstream? No', accessed 15 November 2019 at http:// www.americasquarterly.org/content/can-digitalsharing-economyplatforms-pull -latin-america $\% \mathrm{E} 2 \% 80 \% 99$ s-informal-sector-mainstream-no

Rodríguez-Piñero, M. (2016), 'El trabajo 3.0 y la regulación laboral: por un enfoque creativo en su tratamiento legal', Creatividad y Sociedad, 26, 24-68.

Rodríguez-Piñero, M. (2018), 'La figura del trabajador de plataforma: las relaciones entre las plataformas digitales y los trabajadores que prestan sus servicios', in Francisco Pérez de los Cobos (dir.), El trabajo en plataformas digitales. Análisis sobre su situación jurídica y regulación futura, España: Wolters Kluwer.

Rogers, B. (2016), 'Employment rights in the platform economy: Getting back to basics', Harvard Law \& Policy Review, 10, 480-520.

Sánchez-Urán, Y. (2018), 'El trabajo en plataformas ante los tribunales: un análisis comparado', in Francisco Pérez de los Cobos (dir.), El trabajo en plataformas digitales. Análisis sobre su situación jurídica y regulación futura, España: Wolters Kluwer.

Santos, H. (2020), El Estado y los conflictos laborales y de competencia en el sector del transporte de particulares: la irrupción de Uber en México, Tesis de Maestría [borrador], México: Instituto de Investigaciones Dr. José María Luis Mora.

Solís, V. (2019), 'Fuerte golpe a Uber y Lyft: California aprueba iniciativa para reclasificar a contratistas como empleados', accessed 15 December 2019 at https:// www.univision.com/local/san-francisco-kdtv/fuerte-golpe-a-uber-y-lyft-california -aprueba-iniciativa-para-reclasificar-a-contratistas-como-empleados

Standing, G. (2011), The precariat: The new dangerous class, London: Bloomsbury Academic.

Sundararajan, A. (2017), The collaborative economy: Socioeconomic, regulatory and policy issues, Policy Department: Economic and Scientific Policy, Brussels: European Parliament. 
Todolí, A. (2017), El trabajo en la era de la Economía Colaborativa, España: Editorial Tirant lo Blanch.

Torres Reina, Guillermo (2020), 'El regreso de Uber a Colombia, la próxima pelea', in Semana, 19 de julio, https://www.semana.com/tecnologia/articulo/regreso-de-uber -a-colombia-la-proxima-pelea/683938

Van den Bergh, K. (2019), 'United States', in Isabelle Daugareilh, Christophe Degryse and Philippe Pocher (eds), The platform economy and social law: Key issues in comparative perspective, Brussels: European Trade Union Institute (ETUI). 